\title{
How active ingredient localisation in plant tissues determines the targeted pest spectrum of different chemistries
}

\author{
Buchholz, Anke; Trapp, Stefan
}

Published in:

Pest Management Science

Link to article, DOI:

10.1002/ps.4070

Publication date:

2016

Document Version

Peer reviewed version

Link back to DTU Orbit

Citation (APA):

Buchholz, A., \& Trapp, S. (2016). How active ingredient localisation in plant tissues determines the targeted pest spectrum of different chemistries. Pest Management Science, 72(5), 929-939. https://doi.org/10.1002/ps.4070

\section{General rights}

Copyright and moral rights for the publications made accessible in the public portal are retained by the authors and/or other copyright owners and it is a condition of accessing publications that users recognise and abide by the legal requirements associated with these rights.

- Users may download and print one copy of any publication from the public portal for the purpose of private study or research.

- You may not further distribute the material or use it for any profit-making activity or commercial gain

- You may freely distribute the URL identifying the publication in the public portal

If you believe that this document breaches copyright please contact us providing details, and we will remove access to the work immediately and investigate your claim. 


\section{How active ingredient localisation in plant tissues determines the targeted pest spectrum of different chemistries}

Anke Buchholz (1), Stefan Trapp $\left(2,{ }^{*}\right)$

${ }^{1}$ Syngenta Crop Protection Münchwilen AG, Schaffhauserstrasse 101, 4332 Stein, Switzerland

${ }^{2}$ Technical University of Denmark, Miljoevej 113, 2800 Kongens Lyngby, Denmark *sttr@env.dtu.dk

Running title: Intracellular localization of insecticides

\section{Abstract}

BACKGROUND: The efficacies of four commercial insecticides and of two research compounds were tested against aphids (Aphis craccivora and Myzus persicae), whiteflies (Bemisia tabacl) and red-spotted spider mites (Tetranychus urticae) in intrinsic (oral administration), curative (direct contact spray) and translaminar (arthropods infested on untreated leaf underside) assays. With a newly developed translaminar leaf model, the transport across the leaf cuticle and tissues, and the electro-chemical distribution of test compounds in leaf cells and apoplast were calculated. RESULTS: The comparison of both information sets revealed, that the intracellular localization of active ingredients determines the performance of test compounds against different target pests due to the different feeding behaviours of mites (mesophyll), aphids and whiteflies (the latter mostly vascular system). Polar compounds have a slow adsorption into leaf cells and thus a distribution into apoplast and xylem favourable for targeting 
pests feeding on the vascular bundles. Slightly lipophilic bases get trapped in vacuoles, which is a less favourable place to control Hemipteran pests but well suited to control mites. Non-favourable cellular localisation led to a strong reduction in translaminar efficacy against phloem-feeders. CONCLUSIONS: Prediction and optimization of intracellular localization of pesticides add valuable new information for targeted bioavailability and can indicate directions for improved pesticide design.

Key words: pesticide design; intracellular localization; vacuole trapping; translaminar; aphids; whitefly; mites

\section{Introduction}

Many of the globally widespread pests on agricultural and horticultural crops exhibit a piercing/sucking feeding behaviour on the foliage. These herbivores use specialised stylets to pierce plant cells and to consume large quantities of fluids as their nutritional source, although the feeding sites and resulting tissue damage vary (Walling 2000). Phloem-feeding insects such as aphids and whiteflies traverse their stylets through cuticle, epidermis and mesophyll to reach their feeding sites within the vascular bundle, whereas cell-content feeders such as thrips and spider mites lacerate and consume the contents of epidermis and mesophyll cells. The feeding damage itself and the transmission of plant viruses cause significant losses in plant productivity (IRAC 2014). The agronomic control of sucking pests is most effective with insecticides which not only affect the pests on the leaf surface by contact activity, but which also distribute within the leaf tissues so that sucking pests are controlled by oral uptake. This is important since these pests preferably infest leaf undersides which are not always reached by foliar spray application. 
The prerequisite for a systemic distribution of active ingredients (Al) within the leaf lamina is cuticle penetration. This process can be modulated by an appropriate product formulation which ensures droplet retention on the leaf surface, Al partitioning into cuticular waxes, and which enhances diffusion across the lipid layer (e.g. Miller and Butler Ellis 2000, Zabkiewicz 2007). The subsequent distribution within cells and tissues is however usually determined solely by the physicochemical properties of compounds and has been less well studied, even though this distribution has high impact on the effect of a compound on specific pests because of the differences in feeding behaviour (Bos and Hogenhout 2011, Wondafrash et al. 2013). Targeted bioavailability is an important pillar for the responsible use of agrochemicals in modern agriculture and overall product performance in the field. Increased thresholds in regulatory rules, e.g. against non-target organisms, require either less potent (or more selective) chemicals together with reduced hectare rates - but the agronomic market still needs effective solutions in order to provide the required quality and yields. An improved bioavailability of pesticides in planta would be a successful way to resolve this dichotomy. This applies specifically for sucking pests which have high reproduction rates and typically exhibit a hidden way of life on crops.

Bioassays employing aphids, whiteflies and mites were used to test chemicals for their intrinsic, curative and translaminar insecticidal efficacy. In parallel, we developed a theoretical model that allows to calculate the distribution of neutral and ionizable compounds within the leaf apoplast and the organelles of the symplast, based on the physico-chemical properties of the chemicals and the structure of the plant cells. The model furthermore predicts time for translaminar transfer, and can be combined with other kinetic information such as transfer velocities across cuticles. We then showed 
how the additional information given by these calculations can be used to interpret the biological results, and how to select for compounds with improved field performance.

\section{Material and Methods}

\subsection{Chemicals}

Chemicals studied included on the one hand commercial insecticides, such as thiamethoxam (THMX, neonicotinoid, IRAC 4A, nicotinic acetylcholine receptor agonist), pymetrozine (PYME, IRAC 9B; selective homopteran feeding blocker), cyantraniliprole (CYNT, IRAC 28; ryanodine receptor modulator), spirotetramat (SPAT, tetramic acid derivative; IRAC 23; inhibitor of acetyl CoA carboxylase) and its free acid spirotetramat enol (SPAT enol). On the other hand, data was generated on some hundreds of insecticidal compounds covering a broad range of chemistry (not shown). Two research compounds of a new chemical class were included in this study, oxazoline (OX) and imidazoline (IM). Names, structures, abbreviations, log Kow, pKa, valencies (charge number), molar masses and volumes are shown in Table 1. CYNT, SPAT and SPAT enol are acids (valency -1), OX, IM, PYME and THMX are bases (valency +1 ), but the pKa of the latter two is too low to be of relevance. Compounds were formulated as lab EC (1 mg Al : $10 \mathrm{mg}$ acetone : $20 \mathrm{mg}$ blank formulation (2 parts castor oil ethoxylate, 8 parts N-methyl-2-pyrrolidon, 8 parts dipropylene glycol monomethyl ether)) ensuring proper solution in aqueous test solutions.

\section{$<$ Table 1>}

\subsection{Plants}


French beans, Phaseolus vulgaris L. cv. 'Fulvio' were grown in peat substrate under greenhouse conditions at $21^{\circ} \mathrm{C}$ and $60-65 \% \mathrm{RH}$ under $16: 8 \mathrm{~h}$ light : dark photoperiod. Two week old plants were cut to one first true leaf for 'translaminar assays'. Plants were watered daily as required. Leaf discs of $5 \mathrm{~cm}$ diameter as used in 'curative assays' were cut from fully expanded first true leaves.

\subsection{Arthropods}

All arthropods were obtained from established in-house strains and had no history of pre-exposure to insecticides or acaricides. Non-alate populations of Aphis craccivora Koch, cowpea aphid, and Myzus persicae Sulzer, peach-potato aphid, were reared on pea seedlings (Pisum sativum L.). Whiteflies, Bemisia tabaci Gennadius, were reared on cotton (Gossypium hirsutum L.) and the red-spotted spider mites, Tetranychus urticae Koch, were reared on beans (Phaseolus vulgaris L.).

\subsection{Biological Assays}

Chemical solutions were applied simultaneously by a track sprayer (200 L/ha) to translaminar and curative assays. Infested bean assays were kept at $25^{\circ} \mathrm{C}$ (Aphis and Tetranychus) or $20{ }^{\circ} \mathrm{C}$ (Bemisia), ca. $60 \% \mathrm{RH}$ and a 16:8h (L:D) photoperiod. Experiments for each bean method were set up with at least 5 dose rates using factor 2 dilution steps and 4 replicates per dose rate.

\subsection{Translaminar plant assay}

Pots with bean plants which were standardized to one uniform true-leaf were placed into a grid so that the leaves were kept in a horizontal position during surface application. One day after application plants were infested with model arthropods to the leaf 
underside. Aphids (ca. 90 individuals of mixed Aphis population) and mites (ca. 30 mobile stages) were confined to the lower side of the leaf by a ring of insect glue. Their infestation was done by placing infested plant material into this defined area for $6 \mathrm{~h}$. Whiteflies (ca. 30 adults) were held to the bottom of the leaf by a clip cage $(\varnothing 3.5 \mathrm{~cm}) .7$ days after application, live individuals were counted and mortality was calculated.

\subsection{Curative leaf disc assay}

Cut bean leaf discs were fixed onto aqueous agar (1\%) filled in plastic petri-dishes (ø 5 $\mathrm{cm}$ ). Infestation occurred one day before application (see above). 6 days after application live individuals were counted and mortality was calculated. Due to the mode of action of tetramic acids, lacking direct lethal effects on mature stages (Brück et al. 2009) the efficacy of SPAT and SPAT enol was recorded as control of egg deposition in whitefly assays.

\subsection{Oral ingestion assay (sachet test)}

Several very similar feeding assays have been described (e.g. Mittler and Dadd 1964). In our version, stock solutions of test compounds were diluted by factor 4 in sugar solutions containing $30 \%$ sucrose. We placed $0.6 \mathrm{ml}$ of prepared solutions between two layers of stretched Parafilm ${ }^{\circledR}$ which were fixed on top of a plastic dish $(\varnothing 1.5 \mathrm{~cm})$ containing ca.30 individuals of Aphis or Myzus mixed ages population Six days after infestation we assessed the mortality rate. The corresponding sachet test with Bemisia adults was done very similar: Variations were the reduced sucrose content (15\%) and different dimensions $(0.8 \mathrm{ml}$ solution per sachet and $\varnothing 3 \mathrm{~cm}$ dish). Sachet tests were performed with at least 5 concentrations (max. $12 \mathrm{mg} / \mathrm{L}$ ) using 5 (Bemisia) and 8 
(aphids) replicates per concentration. Assays were kept in a climate cabinet set to $20^{\circ} \mathrm{C}$ and a $14 \mathrm{~h}$ light period. The test shows the intrinsic oral toxicity of a compound.

\subsection{Calculation of efficacies}

Efficacies in different bioassays were assessed as percent mortality for each individual replicate (4 replicates for both types of leaf assays) and dose. If necessary values were corrected by Abbott's formula (Abbott 1925), the treatment with blank formulation served as negative control. The molar effective concentrations $\left(\mathrm{pEC}_{50}\right)$ were calculated following the method by Copeland et al. 1995: Concentrations in $\mathrm{mg} / \mathrm{L}$ causing $50 \%$ efficacy $\left(\mathrm{EC}_{50}\right)$ were determined with the means of corrected mortalities. In addition, the molarity (MW) of different test compounds and a correction factor of 1000 (to unit mol/L) were applied before log transformation.

$$
p\left(E C_{50}\right)=-\log \left(E C_{50} / 1000 / M W\right)
$$

\section{Model Description}

The model allows to calculate the distribution of the active compound between the leaf compartments (apoplast, cytosol, vacuoles, phloem, xylem) and the transfer from the surface of the leaf to the bottom side. Questions to be answered are the transfer velocity across the leaf, but also whether the chemical resides in the apoplastic intercellular space or in cellular compartments such as the cytosol and the vacuole; which concentrations are reached in xylem and phloem, and whether the compound is adsorbed to lipids or is dissolved in aqueous phases. This latter discrimination is important since sucking pests exhibit different preferred feeding sites on cellular compartments, and it is the chemical activity (truly dissolved compound) that triggers toxicity (Trapp et al. 2010). The model is new and is therefore described in detail here. 


\subsection{Basic model structure}

The system is considered as a two-compartment system, where the source compartment is the leaf surface and the sink compartment is the leaf underside (Figure 1). This system resembles the coupled system described in Mayer et al. (2007), and the same analytical solution for mass $\mathrm{m}$ at time $\mathrm{t}$ is used

$m_{1}(t)=1 / 2 m_{0}+1 / 2 m_{0} \times e^{-2 a t}$

$m_{2}(t)=1 / 2 m_{0}-1 / 2 m_{0} \times e^{-2 a t}$

where $\mathrm{m}$ is mass (unit $\mathrm{g}$ ), $\mathrm{t}$ is time (unit $\mathrm{s}$ ) and $\mathrm{a}$ is the kinetic parameter (unit $\mathrm{s}^{-1}$ ) for transfer. As initial condition, all substance mass is in the top layer, thus $m_{1}(t=0)=m_{0}$ (set to unity the following simulations). Concentration is handled as mass per volume. Unit volume was used, i.e. mass equals concentration in the output. The kinetic parameter a can be derived from Fick's $1^{\text {st }}$ Law of Diffusion as

$a=\frac{A_{\text {Leaf }}}{V_{\text {Leaf }}} P$

where $A_{\text {Leaf }}$ is leaf area $\left(5 \mathrm{~m}^{2}\right), V_{\text {Leaf }}$ is leaf volume $\left(0.001 \mathrm{~m}^{3}\right)$ and $P$ is permeability or transfer velocity $\left(\mathrm{m} \mathrm{s}^{-1}\right)$, see below. The percentage of penetration into the leaf is calculated from $100 \times \mathrm{m}_{2}(\mathrm{t}) /\left(1 / 2 \mathrm{~m}_{0}\right)$, because the exchange is finished when top- and downside have equal mass.

<Figure 1> 


\subsection{Molecule fractions from cell model}

The cell model describes the dynamic movement of neutral and ionic molecules across cell membranes and into cell organelles. It has been applied in pharmacology and drug design (Trapp and Horobin 2005, Trapp et al. 2008) but was originally developed for the movement of pesticides in plants (Trapp 2000, Trapp 2003, Trapp 2004). The brief description presented here follows the original model in Trapp and Horobin (2005) and in the book of J. Devillers (Trapp 2009).

Under physiologically relevant conditions, molecules of organic electrolytes exist as ions or in neutral form. The activity ratio $D$ between both is calculated from the $\mathrm{p} K_{a}$ (the negative logarithm of the dissociation constant) by the Henderson-Hasselbalch equation:

$D=\frac{a_{d}}{a_{n}}=10^{i\left(p K_{a}-p H\right)}$

where $a$ is the activity $\left(\mathrm{g} / \mathrm{m}^{3}\right), d$ is the index for dissociation (synonym ionized), $n$ for neutral, $i$ is 1 for bases and -1 for acids. The total concentration $C_{t}$ of the compound is the sum of neutral (n) and dissociated or better ionized (d) molecules. The activity of a compound is the driving force for diffusion (Trapp et al. 2010) and follows from the total concentration $C_{t}\left(\mathrm{~g} / \mathrm{m}^{3}\right)$

$a=f \times C_{t}$

The fraction of freely dissolved neutral molecules, $f_{n}$, is the ratio of activity to total concentration

$f_{n}=a_{n} / C_{t}=\frac{1}{W / \gamma_{n}+K_{n} / \gamma_{n}+D \times W / \gamma_{d}+D \times K_{d} / \gamma_{d}}$ 
where $W$ is the volumetric water fraction, $\gamma$ is the activity coefficient, and $K_{n}$ and $K_{d}$ are the sorption coefficients ( $\mathrm{K}=\mathrm{L} \times \mathrm{K}_{\mathrm{OW}}$ ) of the neutral and the ionized molecule. Per definition, $a_{d}=a_{n} \times D$, and the fraction of freely dissolved ionized molecules, $f_{d}$, is $f_{d}=a_{d} / C_{t}=D \times f_{n}$

The flux across the membrane is calculated with Fick's $1^{\text {st }}$ Law of Diffusion for the neutral molecule with the Nernst-Planck equation for the ion

$$
J=P_{n}\left(a_{n, o}-a_{n, i}\right)+P_{d} \frac{N}{e^{N}-1}\left(a_{d, o}-a_{d, i} e^{N}\right)
$$

where $\mathrm{J}$ is the unit flux $\left(\mathrm{g} / \mathrm{m}^{2} / \mathrm{s}\right), P$ is the permeability of the membrane $(\mathrm{m} / \mathrm{s})$ and $\mathrm{N}$ is the Nernst number, $N=z E F /(R T) ; z$ is the electric charge (synonym valency, for acids -, for bases + ), $F$ is the Faraday constant $\left(96484.56 \mathrm{C} \mathrm{mol}^{-1}\right), E$ is the membrane potential $(\mathrm{V}), R$ is the universal gas constant $\left(8.314 \mathrm{~J} \mathrm{~mol}^{-1} \mathrm{~K}^{-1}\right)$ and $T$ is the absolute temperature $(\mathrm{K})$.

Under steady-state conditions, the net flux is zero, and the concentration ratio between inside and outside the membrane is

$$
\frac{C_{i}}{C_{o}}=\frac{f_{n, o} \times P_{n}+f_{d, o} \times P_{d} \times N /\left(e^{N}-1\right)}{f_{n, i} \times P_{n}+f_{d, i} \times P_{d} \times e^{N} \times N /\left(e^{N}-1\right)}
$$

but for the penetration of the leaf, we use the dynamic solution for $t=1 \mathrm{~h}$, which can be seen in Trapp and Horobin (2005) or Trapp et al. (2008). These equations are used to calculate

- concentration ratio between cytosol and outside apoplast $\mathrm{X}_{\mathrm{Cyt}}$

- concentration ratio between vacuoles and cytosol and thus also vacuoles and apoplast $\mathrm{X}_{\mathrm{Vac}}$

- concentration ratio between outside apoplast and phloem $\mathrm{X}_{\mathrm{Phloem}}$ 
- concentration ratio between outside apoplast and xylem $\mathrm{X}_{\mathrm{Xylem}}$

Properties of the compartments are given in Table 2.

\subsection{Distribution in the leaf}

The total mass of compound in the leaf, $\mathrm{m}_{\mathrm{t}, \mathrm{Leaf}}(\mathrm{mg})$, is the sum of $m_{t, \text { Leaf }}=X_{C y t} \times V_{C y t}+X_{V a c} \times V_{V a c}+X_{a p o} \times V_{a p o}$

The concentrations, related to leaf volume, are $\mathrm{X} / \mathrm{V}_{\text {Leaf }}$, and the distribution inside the leaf can also be expressed as mass fractions $f$ in each compartment (later shown as \%mass) with

$$
f=X \times V / m_{t, \text { Leaf }}
$$

$<$ Table 2>

\subsection{Kinetic parameter permeability $P$}

The kinetics of translaminar molecule movement depends on properties of the leaf and of the chemical. The transfer across cuticles was calculated according to Buchholz et al. (1998) for an isolated apple leaf cuticle with thickness $1.5 \mu \mathrm{m}$. The method uses physico-chemical parameters and plant-specific properties (for details, please see original reference). Once the cuticle barrier is passed, transport of compounds can occur via the apoplastic pathway (i.e. in the intercellular space, $\mathrm{P}_{\mathrm{Apo}}$ ) or by the symplastic pathway (i.e. inside the cells, $P_{\text {Sym }}$ ). 
Apoplast. The diffusion in the apoplastic space of the leaves can be seen as a usual problem of diffusion in a porous medium, often described as

$$
P_{A p o}=\frac{D \times T}{\Delta x} \times f_{a p o}
$$

where $D\left(\mathrm{~m}^{2} \mathrm{~s}^{-1}\right)$ is the diffusion coefficient in the apoplastic space, $T$ is a tortuosity (labyrinth) factor (calculated to 0.072$)$ and $\Delta x(0.1 \mathrm{~mm})$ is the diffusion length; $f_{\text {apo }}(\mathrm{g} / \mathrm{g})$ describes the fraction of chemical that moves via apoplastic pathway. The tortuosity in plant tissue could be successfully described (Trapp et al. 2007) by the Millington and Quirk relation, once developed for unsaturated soil:

$T=\frac{W^{10 / 3}}{(W+G)^{2}}=W^{4 / 3}$

where $W$ and $G$ are water- and gas-filled pore volume fractions $\left(L L^{-1}\right)$. The expression is not unit-true.

Symplastic pathway. It is assumed that the rate-determining steps for chemical transport are on the one hand entry and exit into cells and thus into cytosol, and on the other hand movement from cell to cell. Two resistances are to be crossed, namely an aqueous resistance layer (the liquid film around cells, including cell walls) and the biomembrane (Camenish et al. 1996). Both resistances are in series, and the general equation is therefore

$$
P_{\text {Sym }}=\frac{1}{\frac{1}{P_{\text {aqua }}}+\frac{1}{P_{M}}} \times \frac{f}{n}
$$


where $P_{\text {aqua }}$ is the permeability for the transfer across the aquatic layer (and cell wall), $\mathrm{P}_{\mathrm{M}}$ is the permeability of the biomembrane, $f$ is the fraction in the apoplast (for transfer from outside to inside the cell) or the fraction in the symplast (for transfer from cell to cell), and $n$ is the number of membranes to cross (here $n=10,2$ for in/out, and 8 for 4 cells).

The resistance of an aqueous layer around leaf cells of thickness $d(10 \mu \mathrm{m})$ is

$$
P_{\text {aqua }}=\frac{D_{\text {Chem }}}{d}
$$

where $D_{\text {Chem }}$ is the diffusion coefficient of the chemical in water, estimated from

$$
D_{\text {Chem }}=D_{O 2} \sqrt{\frac{32}{M}}
$$

where $D_{02}$ is the diffusion coefficient of oxygen in water $\left(2 \times 10^{-9} \mathrm{~m}^{2} \mathrm{~s}^{-1}\right.$, Trapp and Matthies 1998) and $\mathrm{M}$ is the molar mass of the compound. Resulting values are similar, but somewhat less than those for the permeability of the cell wall $\left(2.5 \times 10^{-4} \mathrm{~m} \mathrm{~s}^{-1}\right.$, Trapp 2000).

$P_{M}$ is estimated separately for neutral and ionic species:

$$
P_{M}=f_{n} P_{n}+f_{d} P_{d}
$$

where $f_{n}$ and $f_{d}$ are the fractions of neutral and ionic compounds at outside pH (apoplast $\mathrm{pH} 5.6$ for entry) or at cytosol $\mathrm{pH}$ ( $\mathrm{pH} 7.2$, transport from cell to cell). Permeabilities $\mathrm{P}_{\mathrm{n}}$ and $P_{d}\left(\mathrm{~m} \mathrm{~s}^{-1}\right)$ are calculated using the log $\mathrm{K}_{\mathrm{ow}}$ of the neutral $(\mathrm{n})$ or ionized (d) molecule species from the equation (Trapp 2004) 
$\log P=\log K_{O W}-6.7$

Apoplastic and symplastic pathways occur in parallel, and permeabilities are added (Kirchhoff Law, Trapp and Matthies 1998) to give the total permeability P:

$P=P_{a p o}+P_{S y m}$

This $P$ is going into the equation for the kinetic parameter a.

\subsection{Output}

Relevant output parameters shown below are:

- \% distribution in apoplast, cytosol (total and dissolved) and vacuole

- concentrations (ratio to outside apoplast $=1$ ) in phloem and xylem,

- resistances (inverse of transfer velocities) for the apoplastic and symplastic way

- halftime for transfer, $\mathrm{t}_{12}=\ln 2 /(2 \mathrm{a})$

- penetration into leaves (\%) in $1 \mathrm{~h}, 1 \mathrm{~d}$

- solute mobility in the cuticle $\log k^{*}\left(s^{-1}\right)$

- cuticle penetration in \%

For the comparison with bioassays, no absolute values are required, and thus the outside concentration in the apoplast $\mathrm{X}_{\mathrm{apo}}$ of the source compartment at the leaf surface is set to $1\left(\mathrm{~g} / \mathrm{m}^{3}\right)$ for convenience. 


\section{Results}

\subsection{Biological assays}

The three different types of bioassays were performed in order to identify the contribution of the Al bioavailability within the leaf tissue to overall efficacy. To determine the intrinsic insecticidal activity of a compound without any plant interaction, the so called 'sachet test' was applied. This method works for phloem-feeders like aphids and whiteflies (adults). The curative assay provides the strongest biological response since arthropods are not only exposed to the chemical by their feeding activity on the leaf but also due to the direct spray contact. With the translaminar assay, the compound is applied only to the upper leaf surface whereas the pests are feeding from the leaf underside. Pests are controlled by oral uptake only if the compound enters the leaf tissue and distributes to their feeding sites.

Aphids. All compounds showed intrinsically (sachet test, oral administration) good activity against Aphis (Table 3). Very high aphicidal potency was observed with IM and PYME (pEC50 = 7.3). High insecticidal concentrations as applied in this test could cause strong antifeedant effects with Aphis craccivora which might overestimate the efficacy. Therefore, a second aphid species, Myzus persicae, was tested with this method. All compounds showed good intrinsic activity also against this aphid species and quite similar to each other. The different curative activities against Aphis ranged from OX as the most potent compound $(\mathrm{pEC50}=7.1)$, over SPAT $(\mathrm{pEC50}=6.0)$, towards a somewhat lower potency around $\mathrm{pEC} 50=5.4$ of the remaining compounds.

The translaminar assay brings insights into the relevance of transfer and distribution of test compounds for effective pest control. Therefore, it is more relevant to compare 
pEC50 values between the curative and the translaminar assay per compound than performing a cross-chemistry comparison. THMX and PYME lost activity against aphids due to the translaminar exposition by factor 3 and 6 , whereas CYNT, SPAT and IM experienced reductions by factors of 8,16 and 25 , respectively. The strongest reduction in aphid control however was measured for OX with a difference between curative and translaminar approach of a factor of 200 . Interesting is also the difference between SPAT and its enol: The procidal form (SPAT) was less potent in the translaminar bioassay than in the curative spray by a factor of 16 , whereas its cidal form (enol) experienced a reduction by a factor of 126 .

Whiteflies. The test compounds showed better effects on whiteflies in the intrinsic than in the curative tests and the difference between compounds was small (Table 3). The comparison of curative and translaminar whitefly control showed effectively no loss in efficacy for THMX (factor 0.6 increase). CYNT and SPAT exhibited reduced potency by factors of 3 and 8 , respectively, and PYME required 13 times higher rates to reach the same efficacy in a translaminar assay as after a curative spray. The efficacy of IM dropped by factor 25 in the translaminar test system, although it was quite potent against whiteflies after curative spray. The potency of OX fell by the remarkable factor 500 when changing from curative to translaminar assay.

Mites. Methods analogous to the sachet tests are not feasible with mites, and several compounds do not exhibit acaricidal activity. Therefore the comparisons were more limited (Table 3). The differences in potencies between curative and translaminar exposition were much less pronounced than observed for the phloem-feeders aphids and whiteflies. Factors ranged between 3 (OX) and 16 (IM).

\section{$<$ Table 3>}




\subsection{Cell model}

Table 4 shows the calculated mass distribution (\%) in the leaf and the concentration ratio phloem to outside (apoplast) and xylem to outside (apoplast). The highest distribution into the apoplast (i.e. the smallest uptake into leaf cells) was shown by PYME and THMX. The apoplast is filled with aqueous liquid and is reloaded from the xylem sap. SPAT enol shows the highest occurrence in cytosol (54\%). Moreover, most of this is dissolved in cytosol (> 50\%), which makes SPAT enol bioavailable for pests sucking intracellular fluids. SPAT enol also shows an extraordinarily high electrochemical partitioning into the phloem. The fractions of CYNT, SPAT and IM in the cytosol are mostly present in non-dissolved form, i.e. adsorbed to biomembranes and lipid structures. IM has a very high distribution into vacuoles, where substances are compartmentalized and do not participate in intercellular flow, and where substances are not readily available for many sucking insects, either.

\subsection{Cuticle and leaf transfer}

Table 4 also shows the resistances (the inverse of permeabilities $P$, unit $s / m$ ) in apoplast $\left(1 / \mathrm{P}_{\mathrm{apo}}\right)$ and symplast $\left(1 / \mathrm{P}_{\text {Sym }}\right)$, overall half-time for transfer $t_{1 / 2}(\mathrm{~d})$ from top to downside and \% penetration across leaf and cuticle. Diffusion within cuticular waxes, solute mobility $\mathrm{k}^{*}\left(\mathrm{~s}^{-1}\right)$, is calculated from molar volume of test compounds for an apple (Malus domestica) leaf cuticle (Buchholz et al. 1998). Table 4 also shows the calculated cuticle transfer rate (\% penetration within $24 \mathrm{~h})$ for this reference cuticle. OX, PYME and THMX show the fastest, SPAT and CYNT slowest cuticle transfers. Compared to the slow diffusion through cuticles, the distribution across the leaf lamina is fast for all compounds. CYNT, SPAT and SPAT enol have similar resistances $(r=1 / \mathrm{P})$ towards transport in symplast and apoplast, while OX, PYME and THMX move much faster via 
diffusion in the apoplastic space than in the symplast. The fastest translaminar transport is, according to the model, for PYME, THMX and OX and the slowest for IM (which is retained in vacuoles). The translaminar test on beans was started one day after application of $\mathrm{Al}$, and penetration after $\mathrm{t}=1 \mathrm{~d}$ was completed for all compounds except IM. The numbers are without penetration across the cuticle, but in fact, the calculated diffusion through the model leaf cuticle (apple) is for all compounds transport limiting.

\section{$<$ Table 4>}

\section{Discussion}

\subsection{Comparison of bioassays and model predictions}

The first step for translaminar pest control is the crossing of the leaf cuticle. Compounds with slow transfer (complete solubility within cuticular waxes and subsequent desorption into adjoining cell wall, i.e. apoplast, presumed) will have a weaker effect on pests feeding on the bottom side of the leaf. The mobility of compounds in thin leaf cuticles of annual crops like vegetables is not known. However, one can expect significant lower barrier qualities (i.e. faster diffusion across) of bean cuticles as measured for e.g. in deciduous trees like apple, whereas the exponential dependency of permeabilities on molar volume as described for many different plant species (Buchholz 2006) will remain comparable. Figure 2 shows the mortality ( $\mathrm{pEC50}$ ) of aphids in the translaminar bean assay versus the calculated mobility across apple leaf cuticles $\left(\log k^{*}\right)$. The top right corner represents aphicides with the best field results (THMX), measured by the rate efficacy ratio or low rates per hectare. Compounds with high mobility in plant cuticles typically show good translaminar aphid control (groups indicated by rings). 
CYNT and SPAT have the slowest calculated cuticle penetration (Table 4, Figure 2), and this is reflected by a strong reduction of efficacy from curative to translaminar application, as seen in the tests (Table 3) with aphids, whiteflies and mites (SPAT). The mobility of IM within cuticular waxes is moderate but it additionally has a high retention in vacuoles and thus an overall slow translaminar distribution (Table 4).

According to the model calculations, penetration into leaf tissues and further transfer across the entire leaf lamina is fast compared to cuticle penetration and thus not limiting for compound distribution. This implies that the vertical transport across the leaf (distribution from the upper epidermis to the epidermis of the leaf underside) has less impact on the efficacy of an Al applied than facilitating high sorption into cuticular waxes. Nonetheless, compounds with rapid translaminar transfer (THMX, PYME) seem to have better translaminar activity, too. It is possible that the model kinetics needs some adjustment here, e.g. for leaf thickness.

\section{$<$ Figure $2>$}

The distribution of compounds across the various leaf tissues and the different cell compartments can have a high impact on the resulting effect against piercing/sucking pests which possess widely differing feeding behaviours: The two-spotted spider mite uses specialized stylets to puncture epidermal cells of the host tissue; subsequent withdrawal of cellular contents leads to collapse of the underlying mesophyll tissue and formation of a chlorotic lesion at the site of feeding. Severe infestations usually result in complete desiccation and death of the affected tissue (Baker and Connell 1963, Li et al. 2002). Stylet penetration through the abaxial leaf surface provides phloem-feeders with an energy efficiency advantage because of the shorter distance to the sieve elements and also because of easier penetration through loosely arranged spongy parenchyma 
cells near to the compact palisade parenchyma cells that are closely associated with adaxial leaf surfaces (Chu et al. 1995). Aphids may puncture virtually every cell from the epidermis to the sieve element (Tjallingi et al. 1993) for host recognition and while searching for the feeding sites (Miles 1999; Annan et al. 2000). Electrical penetration graph (EPG) signals enable a precise discrimination of intracellular stylet activities (reviewed in Powell et al. 2006) and suggest aphids ingesting cytosolic fluid, but the puncture of the tonoplast (membrane surrounding the vacuole) which is often close to the plasma membrane is not distinguishable. Whiteflies in contrast do not ingest during cellular punctures which could explain why whiteflies rarely transmit nonpersistent viruses, and it has been postulated that they are simply testing for sieve elements (Johnson and Walker 1999). Aphids and whiteflies not only feed on the phloem sap but also pierce into xylem vessels to access water and mineral salts required for osmoregulation and rehydration (Powell and Hardie 2002; Daniels et al. 2009). A simplified feeding scheme of piercing/sucking arthropods used in our study is shown in Table 5.

There are indications for a co-evolution of Bemisia tabaci with its host plants like tobacco: if whiteflies do not ingest the cell contents of mesophyll cells they avoid exposure to toxic alkaloids like nicotine. This would be a behavioural defence tactic against toxins in addition to metabolic mechanisms (Kliot et al. 2014). The stylet of whiteflies is described not to enter cells (Freeman et al. 2001) so that high Al concentrations outside of cells (i.e. in the apoplast) should result in good translaminar Bemisia control. Of course, evolution has led to myriads of plant - herbivore interactions (Walling 2000, Bos and Hogenhout 2011), and these rules on feeding behaviour do not hold generally. 


\section{$<$ Table 5>}

When interpreting relative toxicities, the data of the translaminar effect concentration need to be set into relation to the intrinsic (oral administration) and also to the curative (contact spray) toxicity. OX has a strong intrinsic potency on all species (in particular on aphids), the efficacy however, is extremely reduced by translaminar exposition for whiteflies and aphids, while little reduction is seen for mites. Mites are the only test species that feed from whole cells, including vacuoles, where most of the OX resides. OX also has the smallest distribution into phloem, where aphids and whiteflies predominantly feed.

IM belongs to the same chemistry type as OX, acting on octopamine receptors (O'Sullivan et al. 2013, Pabba et al. 2014). More than OX, is IM trapped in vacuoles, but there is a negligible amount in the apoplast (the lowest of all test compounds), and it is mostly adsorbed inside the cytosol. The stylet of whiteflies reaches the vascular system without feeding on mesophyll cells (intercellular pathway) so that they are not exposed to IM after translaminar application. Consequently, the effect of IM on Bemisia via translaminar application is very weak and would require unacceptable high application rates. IM does not maintain its high potency against aphids (as seen in intrinsic assays) when tested translaminarily, whereas the reduction is only minor for mites which suck the whole cell content of cells and get the Al from both cell compartments (cytosol and vacuole) (Table 3).

Compared to IM has OX more favourable physico-chemical properties (it is less lipophilic; i.e. more polar) resulting in an 'optimised' Al localisation for sucking pests. The mass fraction in vacuoles is lower and more Al is present in the apoplastic liquid. Thus, the translaminar movement $\left(t_{1 / 2}\right)$ is also much faster. Compared with THMX, 
however, which is even more polar and does not ionize at $\mathrm{pH}$ values present inside leaves, the physico-chemical parameters for OX are not yet in the 'ideal' range: the major fraction resides in vacuoles, very little is present in phloem, the apoplastic fraction is still much lower than for THMX, and the bioavailability for Hemipteran pests remains limited. This might explain why, despite the very high intrinsic activity (Aphis) and favourable properties for cuticle penetration $\left(\log k^{*}\right)$, OX did not reach sufficient translaminar aphid control. Lower intrinsic potency as measured with Bemisia then effectively abolished the translaminar pest control.

THMX and PYME are highly mobile in the apoplast (which is loaded from the xylem), and have comparatively little reduction in efficacy towards whiteflies and aphids from curative to translaminar application. Both compounds are mainly present in dissolved phase and thus are rapidly bioavailable, and have the highest translaminar toxic effect. Figure 3 is a plot of the log effective concentration of 50\% mortality (pEC50) for Bemisia in the translaminar versus the plant independent intrinsic activity in sucrose solution. This plot illustrates how the tested compounds diverge in their translaminar activity despite quite similar intrinsic potency against Bemisia adults (beside OX). The different bioavailability against the target pest is reflected by the symbol size indicating the calculated mass fractions in the apoplast; i.e. one explanation for the different translations of insecticidal potency intro translaminar whitefly control. The translaminar efficacy could be enhanced by tailored formulation which increases cuticle penetration. But the optimization of intracellular localization as indicated with these examples opens another approach.

The intrinsic potency of CYNT is comparable to THMX, but it requires higher doses to reach the comparable effect. CYNT, which is a very strong insecticide against chewing 
pests like Lepidoptera, has a lower exposition to sucking insects: it is less available via apoplast and it adsorbs much more strongly to cell compartments.

SPAT is the procide of SPAT enol and gets readily activated in leaf tissues by ester cleavage (Brück et al.). The pKa of the very weak acid SPAT is rather high (10.7), and it is primarily present as neutral species, which brings benefit for cuticle penetration. The enol has a pKa of 5.2, which leads to the ion trap effect in phloem and cytosol, and thus to a preferable distribution in leaf tissues. SPAT enol has a high mass fraction in cytosol, in which it is furthermore freely dissolved and thus bioavailable to pests feeding on plant fluids. One can expect that the measured efficacy of SPAT on leaf assays is dominated by the free enol form. The better translaminar pest control of the neutral procide therefore confirms the cuticle penetration as crucial step.

\subsection{Consequences for insecticide development}

Lipophilic basic compounds never have been commercialized as insecticides against sucking pests in crop protection (only in animal health against ectoparasitoids as e.g. amitraz). The postulated Al localisation in vacuoles based on the generic model in combination with the measured biological effects sheds light on the reason for this lack of success. OX and IM are weak, lipophilic bases, and despite high intrinsic activity against all pests investigated, their translaminar effect against phloem-feeders is the lowest of all tested compounds. For weak, non-polar bases, an ion trap occurs that leads to accumulation of these compounds in vacuoles, due to the low $\mathrm{pH}$ there $(\mathrm{pH}$ 5.5). Trapping in vacuoles is not favourable when sucking insects like Hemiptera are targeted. Neither are vacuoles a preferred food source, nor do they participate in systemic transport. The opposite is seen for weak, slightly lipophilic acids. These are frequently used as pesticides, in particular as herbicides, starting with the classical 2,4- 
D, mecoprop, and the sulfonyl ureas (Börner 1990). The reason is their ion trap effect of opposite polarity that leads to a systemic transport in the alkaline phloem (Kleier et al. 1988, Bromilow and Chamberlain 1995).

Trapping lipophilic weak bases in acidic vesicles and vacuoles is a rather common principle in the plant empire for alkaloids, as has been experimentally confirmed by Hauser and Wink (1990) for plant cells (but also for lysosomes in human cells (De Duve 1974; Kornhuber et al. 2010)). An example is nicotine that has a pKa of 8.2 and a log Kow (neutral) of 0.7 (ACD 2010). Nicotine is used as an insecticide, but is only applied as contact insecticide. Sharing a common mode of action with nicotine, the synthetic neonicotinoids (Maienfisch et al. 2001, Jeschke and Nauen 2010) comprise one of the most successful chemical class of insecticides, also used to control whiteflies as agronomic pest. Imidacloprid has a log Kow of 0.5 (between pH 2 and 10) and is nonionised in this range. Acetamiprid has similar properties (log Kow 0.9). Both compounds have a cationic group, which makes them rather polar compounds, but the pKa is so low $(<1)$ that it does not affect intracellular distribution. Clothianidin is a mostly un-charged amphoteric compound (pKa base 2.4, acid 10.8; both of no physiological relevance), nitenpyram has very weak cationic groups (pKa 2 and 0.1 ). These compounds have properties similar to PYME and THMX which were most successful for translaminar pest control in our study. Thus, the step from nicotine to the neonicotinoids - which were discovered in an unrelated manner - involves improved electro-chemical partition behaviour for better bioavailability to insects sucking from leaves (Jeschke and Nauen 2010). Of course, there are exceptions: Thiacloprid has a basic pKa of 7 and it is used against aphids and whiteflies, nithiazine is a weak base, pKa 7.6.

5.3 Findings from the medical field 
Intracellular localization (IL) is known since long to affect transport of pesticides (Kleier et al. 1988, Trapp 2000), and the cell model was first presented on the XIlth Pesticide Congress in Piacenca, Italy (Trapp 2003). To our knowledge, however, the prediction of IL has not yet been applied in pesticide research to interpret toxic effects. The situation is very different in medical research. Intracellular targeting is seen as an emerging and promising tool in drug design (Stepensky 2010, Zhou et al. 2011). The feasibility to predict intracellular localization of chemicals is expected to lead "Toward a new age of cellular pharmacokinetics in drug discovery" (quoted from Zhou et al. 2011). It is expected that "intracellularly targeted drug delivery approaches will be the focus of intensive research during the next decade" (Stepensky 2010), and that "Mathematical modeling approaches will be of great importance to determine the barriers and limiting factors in intracellular drug delivery". Silver (2011) sees the dynamic cell model "an excellent starting point for further analysis of the uptake of ionizable antibacterials" (Silver 2011), and Alaskosela see this model as "an important step forward in the analysis of subcellular drug distribution" (Alakoskela et al. 2009). Either the medical scientists are generally more euphoric, or the value gain from IL prediction in medical science is really high. It is important to note that the cell model (for mitochondriatargeting drugs and stains) has been validated repeatedly with medical data (Horobin et al. 2007, Tischbirek et al. 2012). In medical science, there is a pressing need to clarify the cellular pharmacokinetics and thus evaluate the efficacy of drugs in the target cells (Zhou et al. 2011), and the intracellular distribution has been identified to be a determinant of toxic effects of molecules (Alakoskela et al. 2009). This message opens the door wide to use IL in pesticide research, also for predictions on Al distribution in the target, the pests, itself.

\section{Conclusions}


In conclusion, the parallel use of bioassays and intracellular localization model adds value to pesticide research. Only two measured parameters, $\log \mathrm{P}$ and $\mathrm{pKa}$, can give a reasonable estimate of the "foliar systemic" behaviour of a compound, and help in interpreting results of bioassays. Together with the knowledge of the biology of the target pest, the model allows to postulate a hypothesis on the bioavailability of a research compound. This can give additional steer in chemical design and an early indication where formulation might improve bioefficacy.

\section{Acknowledgement}

The authors would like to acknowledge the excellent contributions and valuable discussions on this work from Werner Reiner, Friedrich Wassmann, Anthony O'Sullivan, Torsten Luksch, Laura Mallon and André Jeanguenat.

\section{References}

\begin{tabular}{|l|l|}
\hline 9 & $\begin{array}{l}\text { Abbott WS. A method for computing the effectiveness of an insecticide. J } \\
\text { Econ Entomol 18:265-267 (1925). }\end{array}$ \\
\hline 44 & $\begin{array}{l}\text { ACD Advanced Chemistry Development Inc. 2010. ACD/I-Lab. Toronto, } \\
\text { Ontario, CA. https://ilab.acdlabs.com/iLab2/index.php }\end{array}$ \\
\hline 50 & $\begin{array}{l}\text { Alakoskela J-M, Vitovic P, KinnunenPKJ. Screening for the drug- } \\
\text { phospholipid interaction: Correlation to phospholipidosis. ChemMedChem } \\
4: 1224-1251 \text { (2009). } \\
29\end{array} \begin{array}{l}\text { Annan IB, Tingey WM, Schaefers GA et al. Stylet penetration activities by } \\
\text { Aphis craccivora (Homoptera: Aphididae) on plants and excised plant parts } \\
\text { of resistant and susceptible cultivars of cowpea (Leguminosae). Annals }\end{array}$ \\
\hline
\end{tabular}




\begin{tabular}{|c|c|}
\hline & Entomol. Soc. Am 93(1):133-140 (2000) \\
\hline 24 & $\begin{array}{l}\text { Baker JE, Connell WA. The Morphology of the Mouthparts of Tetranychus } \\
\text { atlanticus and Observations on Feeding by this Mite on Soybeans. Annals of } \\
\text { the Entomological Society of America 56: (6) 733-736 (1963). }\end{array}$ \\
\hline 38 & Börner H. Unkrautbekämpfung. Gustav Fischer, Jena (1995). \\
\hline 5 & $\begin{array}{l}\text { Bos JIB, Hogenhout SA. Effectors in Plant-Insect Interactions. in Effectors } \\
\text { in Plant-Microbe Interactions ed. by Martin F and Kamoun S. Wiley- } \\
\text { Blackwell, Oxford, UK.pp. } 355-375 \text { (2011). }\end{array}$ \\
\hline 40 & $\begin{array}{l}\text { Bromilow RH, Chamberlain K. Principles governing uptake and transport of } \\
\text { chemicals. in Plant Contamination: Modeling and Simulation of Organic } \\
\text { Chemical Processes ed. by Trapp S and Mc Farlane C, Lewis Pub., Boca } \\
\text { Raton, pp } 37 \text { (1995). }\end{array}$ \\
\hline 7 & $\begin{array}{l}\text { Brück E, Elbert A, Fischer R, Krueger S, Kühnhold J, Klueken M, Nauen R, } \\
\text { Niebes J-F, Reckmann U, Schnorbach H-J, Steffens R, van Waetermeulen } \\
\text { X. Movento®, an innovative ambimobile insecticide for sucking insect pest } \\
\text { control in agriculture: Biological profile and field performance. Crop } \\
\text { Protection 28(10):838-844 (2009). }\end{array}$ \\
\hline 23 & $\begin{array}{l}\text { Buchholz A. Characterisation of the diffusion of nonelectrolytes across plant } \\
\text { cuticles -properties of the lipophilic pathway. J Exp Bot 57: 2501-2513 } \\
\text { (2006). }\end{array}$ \\
\hline 22 & $\begin{array}{l}\text { Buchholz A, Baur P, Schönherr J. Differences among plant species in } \\
\text { cuticular permeabilities and solute mobilities are not caused by differential } \\
\text { size selectivities. Planta 206: } 322-328 \text { (1998). }\end{array}$ \\
\hline
\end{tabular}




\begin{tabular}{|c|c|}
\hline 20 & $\begin{array}{l}\text { Camenisch G, Folkers G, van de Waterbeemd H. Review of theoretical } \\
\text { passive drug adsorption models: Historical background, recent } \\
\text { developments and limitations. Pharmaceutica Acta Helvetine 71: 309-327 } \\
\text { (1996). }\end{array}$ \\
\hline 26 & $\begin{array}{l}\text { Chu CC, Henneberry TJ, Cohen AC. Bemisia argentifolii (Homoptera: } \\
\text { Aleyrodidae): host preference and factors affecting oviposition and feeding } \\
\text { site preference. J Environ Entomol 24: 254-360 (1995). }\end{array}$ \\
\hline 10 & $\begin{array}{l}\text { Copeland RA, Lombardo D, Giannaras J, Decicco CP. Estimating KI values } \\
\text { for tight binding inhibitors from dose-response plots. Bioorganic \& Medicinal } \\
\text { Letters 5(17):1947-1952 (1995). }\end{array}$ \\
\hline 33 & $\begin{array}{l}\text { Daniels, M; Bale, JS; Newbury, HJ; Lind, RJ; Pritchard, J. A sublethal dose } \\
\text { of thiamethoxam causes a reduction in xylem feeding by the bird cherry-oat } \\
\text { aphid (Rhopalosiphum padi), which is associated with dehydration and } \\
\text { reduced performance. J. Insect Physiol. } 55 \text { (8): 758-765 (2009) }\end{array}$ \\
\hline 42 & $\begin{array}{l}\text { De Duve C, De Barsy T, Poole B, Trouet A, Tulkens P, Van Hoof F. } \\
\text { Commentary. Lysosomotropic agents. Biochemical Pharmacology 23:2495- } \\
2531 \text { (1974). }\end{array}$ \\
\hline 35 & $\begin{array}{l}\text { Freeman TP, Buckner JS, Nelson DR, Chu CC, Henneberry TJ. The } \\
\text { process of stylet penetration by the silverleaf whitefly, Bemisia argentifolii } \\
\text { (Homoptera: Aleyrodidae) into host leaf tissue. Annals of the Entomological } \\
\text { Society of America 94:761-768 (2001). }\end{array}$ \\
\hline 41 & $\begin{array}{l}\text { Hauser MT, Wink M. Uptake of alkaloids by latex vesicles and isolated } \\
\text { mesophyll vacuoles of Chelidonium majus (Papaveraceae). Z. Naturforsch. }\end{array}$ \\
\hline
\end{tabular}




\begin{tabular}{|c|c|}
\hline & \\
\hline 51 & $\begin{array}{l}\text { Horobin RW, Trapp S and Weissig V. Mitochondriotropics: A review of their } \\
\text { mode of action, and their applications for drug and DNA delivery to } \\
\text { mammalian mitochondria. J Contr Rel 121(3):125-136 (2007). }\end{array}$ \\
\hline 2 & $\begin{array}{l}\text { IRAC Insecticide Resistance Action Committee. Pest information, pest } \\
\text { biology profiles (Bemisia / Myzus / Tetranychus). http://www.irac- } \\
\text { online.org/pests/ }\end{array}$ \\
\hline 46 & $\begin{array}{l}\text { Jeschke P, Nauen R. Neonicotinoid Insecticides and Addendum: The } \\
\text { Neonicotinoid Insecticides, in Insect control ed. by Gilbert LI, Gill SS. } \\
\text { Academic Press, London, UK (2010). }\end{array}$ \\
\hline 31 & $\begin{array}{l}\text { Johnson DD, Walker GP. Intracellular punctures by the adult whitefly } \\
\text { Bemisia argentifolii on DC and AC electronic feeding monitors. Entomologia } \\
\text { Experimentalis et Applicata. 92.(3) } 257-270 \text { (1999). }\end{array}$ \\
\hline 39 & Kleier DA. Phloem mobility of xenobiotics. Plant Physiol. 86:803-810 (1988). \\
\hline 34 & $\begin{array}{l}\text { Kliot A, Kontsedalov S, Ramsey JS, Jander G, Ghanim M. Adaptation to } \\
\text { nicotine in the facultative tobacco-feeding hemipteran Bemisia tabaci. Pest } \\
\text { Manag Sci. } 70 \text { (10): } 1595-1603 \text { (2014). }\end{array}$ \\
\hline 43 & $\begin{array}{l}\text { Kornhuber J, Henkel AW, Groemer TW, Städtler S, Welzel O, Tripal P, } \\
\text { Rotter A, Bleich S, Trapp S. Lipophilic cationic drugs increase the } \\
\text { permeability of lysosomal membranes and modulate drug accumulation and } \\
\text { interaction. J Cell Physiol 224:152-164 (2010). }\end{array}$ \\
\hline 25 & $\begin{array}{l}\text { Li C, Williams MM, Loh YT, Lee GI, Howe GA. Resistance of Cultivated } \\
\text { Tomato to Cell Content-Feeding Herbivores Is Regulated by the }\end{array}$ \\
\hline
\end{tabular}




\begin{tabular}{|c|c|}
\hline & gg Pathway. Plant Physiol. 130: 494-503 (2002). \\
\hline 45 & $\begin{array}{l}\text { Maienfisch P, Huerlimann } H \text {, Rindlisbacher A, Gsell L, Dettwiler } H \text {, } \\
\text { Haettenschwiler J, Sieger E, Walti M. The discovery of thiamethoxam: a } \\
\text { second-generation neonicotinoid. Pest Manag Sci 57(2):165-176 (2001). }\end{array}$ \\
\hline 8 & $\begin{array}{l}\text { Mittler TE, Dadd RH. An Improved Method for Feeding Aphids on Artificial } \\
\text { Diets. Annals of the Entomological Society of America 57(1): 139a (1964). }\end{array}$ \\
\hline 28 & Miles PW. Aphid saliva. Biol Rev 74:41-85 (1999). \\
\hline 3 & $\begin{array}{l}\text { Miller } \mathrm{PCH} \text {, Butler Ellis MC. Effects of formulation on spray nozzle } \\
\text { performance for applications from ground-based boom sprayers. Crop } \\
\text { Protection } 19 \text { (8-10): 609-615 (2000). }\end{array}$ \\
\hline 36 & $\begin{array}{l}\text { O'Sullivan AC, Schaetzer JH, Lüthy C, Mathews CJ, Elliott C, Pitterna T, } \\
\text { Pabba J, Jacob O, Buchholz A, Blythe J. Synthesis and insecticidal activity } \\
\text { of new benzyl- and indanyl- oxazolines, thiazolines, and imidazolines. In: } \\
\text { Abstracts of papers of the American Chemical Society, } 115516^{\text {th }} \text { St, NW, } \\
\text { Washington, DC } 20036 \text { USA: Amer. Chemical Soc. (2013). }\end{array}$ \\
\hline 37 & $\begin{array}{l}\text { Pabba J, O'Sullivan AC, Schaetzer, JH. Lüthy C, Pitterna T, Jacob O, } \\
\text { Buchholz A. Synthesis and insecticidal activity of aryloxy-alkylimidazolines. } \\
\text { 13th International Congress of Pesticide Chemistry (IUPAC), San Francisco. } \\
\text { AGRO } 318 \text { (2014). }\end{array}$ \\
\hline 30 & $\begin{array}{l}\text { Powell G, Hardie J. Xylem ingestion by winged aphids, in: Proceedings of } \\
\text { the } 11 \text { th International Symposium on Insect-Plant Relationships. Series } \\
\text { Entomologica } 57: 103-108(2002) \text {. }\end{array}$ \\
\hline 32 & Powell G, Tosh CR, Hardie J. Host P \\
\hline
\end{tabular}




\begin{tabular}{|c|c|}
\hline & $\begin{array}{l}\text { Evolutionary, and Applied Perspectives. Annu. Rev. Entomol. 51: 309-30 } \\
\text { (2006). }\end{array}$ \\
\hline 49 & $\begin{array}{l}\text { Silver LL. Challenges of Antibacterial Discovery. Clinical Microbiology } \\
\text { Reviews 24(1):71-109 (2011). }\end{array}$ \\
\hline 47 & $\begin{array}{l}\text { Stepensky D. Quantitative aspects of intracellularly-targeted drug delivery. } \\
\text { Pharm Res 27: } 2776-2780 \text { (2010). }\end{array}$ \\
\hline 52 & $\begin{array}{l}\text { Tischbirek CH, Wenzel EM, Zheng F, Huth T, Amato D, Trapp S, Denker A, } \\
\text { Welzel O, Lueke K, Svetlitchny A, Rauh M, Deusser J, Schwab A, Rizzoli } \\
\text { SO, Müller CP, Alzheimer C, Kornhuber J, Groemer TW. Use-dependent } \\
\text { inhibition of synaptic transmission by the secretion of intravesicularly } \\
\text { accumulated antipsychotic drugs. NEURON 74:1-15 (2012). }\end{array}$ \\
\hline 27 & $\begin{array}{l}\text { Tjallingii WF, Hogen Esch T. Fine structure of aphid stylet routes in plant } \\
\text { tissues in correlation with EPG signals. Physiological Entomology 18: 317- } \\
328 \text { (1993). }\end{array}$ \\
\hline 15 & $\begin{array}{l}\text { Trapp S. Modeling uptake into roots and subsequent translocation of neutral } \\
\text { and ionisable organic compounds. Pest Manage Sci 56:767-778 (2000). }\end{array}$ \\
\hline 16 & $\begin{array}{l}\text { Trapp S. Review of plant uptake models. Proceedings of the XII Symposium } \\
\text { Pesticide Chemistry June } 4-6^{\text {th }} 2003 \text {, Piacenca, Italy (2003). }\end{array}$ \\
\hline 17 & $\begin{array}{l}\text { Trapp S. Plant uptake and transport models for neutral and ionic chemicals. } \\
\text { Environ Sci \& Pollut Res 11:33-39 (2004). }\end{array}$ \\
\hline 13 & $\begin{array}{l}\text { Trapp S, Horobin RW. A predictive model for the selective accumulation of } \\
\text { chemicals in tumor cells. Eur Biophys } J \text { 34:959-966 (2005). }\end{array}$ \\
\hline
\end{tabular}




\begin{tabular}{|c|c|}
\hline 21 & $\begin{array}{l}\text { Trapp S, Matthies M. Chemodynamics and Environmental Modeling. } \\
\text { Heidelberg: Springer (1998) }\end{array}$ \\
\hline 19 & $\begin{array}{l}\text { Trapp S, Cammarano A, Capri E, Reichenberg F, Mayer P. Diffusion of PAH } \\
\text { in potato and carrot slices and application for a potato model. Environ. Sci. } \\
\text { Technol. } 41: 3103-3108(2007)\end{array}$ \\
\hline 14 & $\begin{array}{l}\text { Trapp S, Rosania GR, Horobin RW, Kornhuber J. Quantitative modeling of } \\
\text { selective lysosomal targeting for drug design. European Biophysics Journal } \\
\text { 37:1317-1328 (2008) }\end{array}$ \\
\hline 18 & $\begin{array}{l}\text { Trapp S. Bioaccumulation of polar and ionizable compounds in plants. in } \\
\text { Ecotoxicology modeling. ed. by J. Devillers. Springer, Dordrecht (2009). }\end{array}$ \\
\hline 11 & $\begin{array}{l}\text { Trapp S, Franco A, Mackay D. Activity-based concept for transport and } \\
\text { partitioning of ionizing organics. Environ Sci Technol 44:6123-6129 (2010). }\end{array}$ \\
\hline 1 & $\begin{array}{l}\text { Walling L. The Myriad Plant Responses to Herbivores. J Plant Growth Regul } \\
\text { 19:195-216 (2000). }\end{array}$ \\
\hline 6 & $\begin{array}{l}\text { Wondafrash M., Van Dam NM., Tytgat TOG. Plant systemic induced } \\
\text { responses mediate interactions between root parasitic nematodes and } \\
\text { aboveground herbivorous insects. Front. Plant Sci. 4: art. } 87 \text { (2013) }\end{array}$ \\
\hline 53 & $\begin{array}{l}\text { WO 2008/017816. Lüthy C., O'Sullivan, AC. Schaetzer, JH. Chemical } \\
\text { compounds. }\end{array}$ \\
\hline 54 & $\begin{array}{l}\text { WO 2008/098657. O'Sullivan AC, Lüthy C., Schaetzer, JH. Chemical } \\
\text { compounds. }\end{array}$ \\
\hline 4 & Zabkiewicz JA.. Spray formulation efficacy - \\
\hline
\end{tabular}




\begin{tabular}{|l|l|}
\hline 48 & $\begin{array}{l}\text { perspectives. Crop Protection } 26 \text { (3): 312-319 (2007). } \\
\text { Zhou F, Zhang J, Li P, Niu F, Wu X, Wang G, Roberts M. Toward a new age } \\
\text { of cellular pharmacokinetics in drug discovery. Drug Metabolism Reviews } \\
\mathbf{4 3 ( 3 ) : 3 3 5 - 3 4 5 ~ ( 2 0 1 1 ) . ~}\end{array}$ \\
\hline
\end{tabular}






- Spray droplet
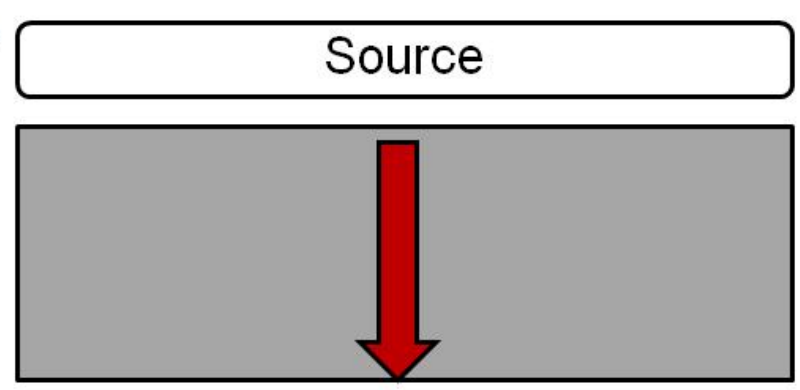

Sink

Figure 1. Scheme of the model problem and of the model system. Leaf modified after 'Digital frog international'. 


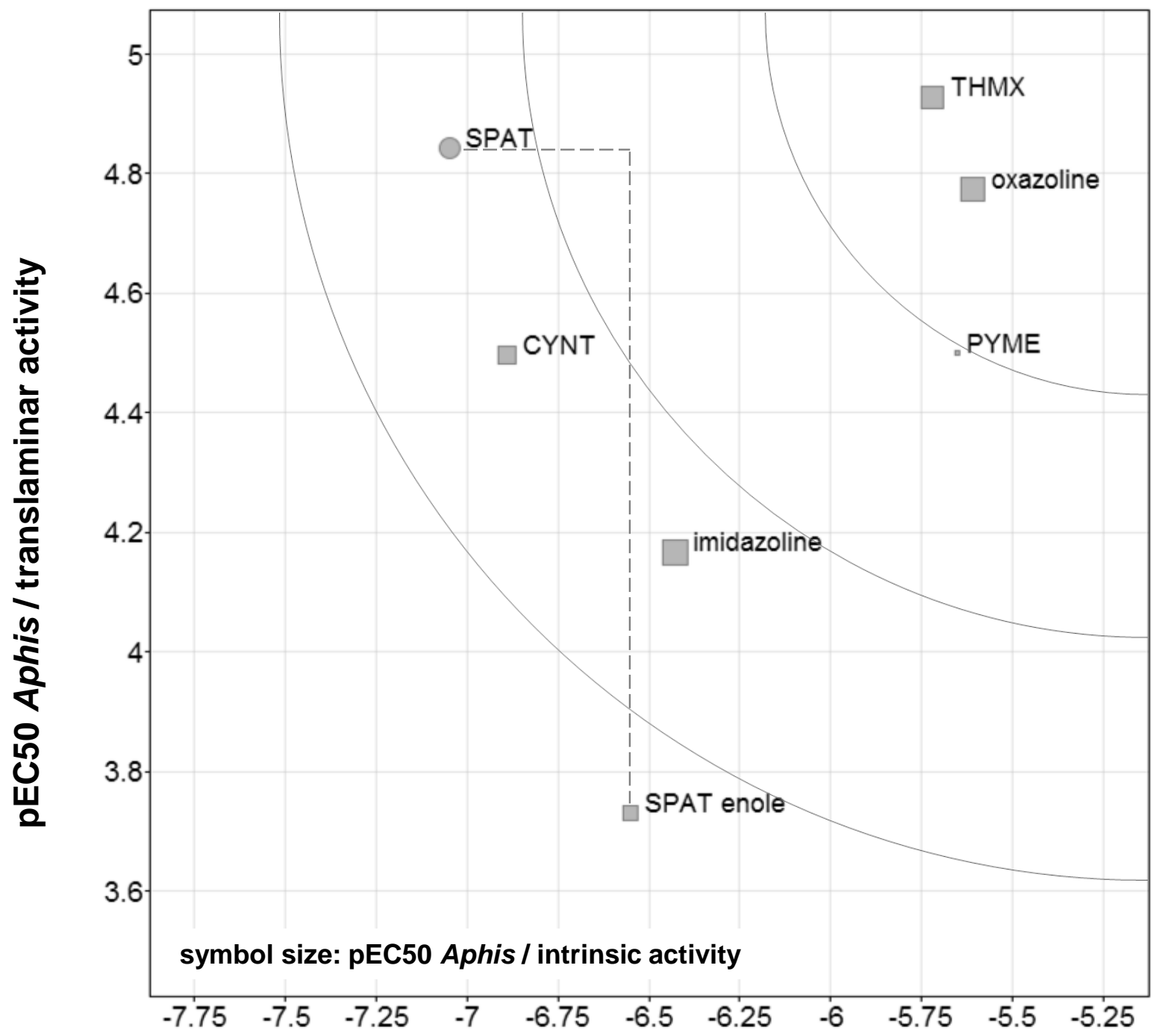

Malus leaf cuticle, $\log \mathbf{k}^{*}$

Figure 2. Plot of the log effective concentration of 50\% mortality (pEC50) against Aphis craccivora in the translaminar assay versus the calculated mobility across apple leaf cuticles $\left(\log k^{*}\right)$. The symbol size reflects the intrinsic activity (pEC50; sachet test system) against Aphis craccivora. 


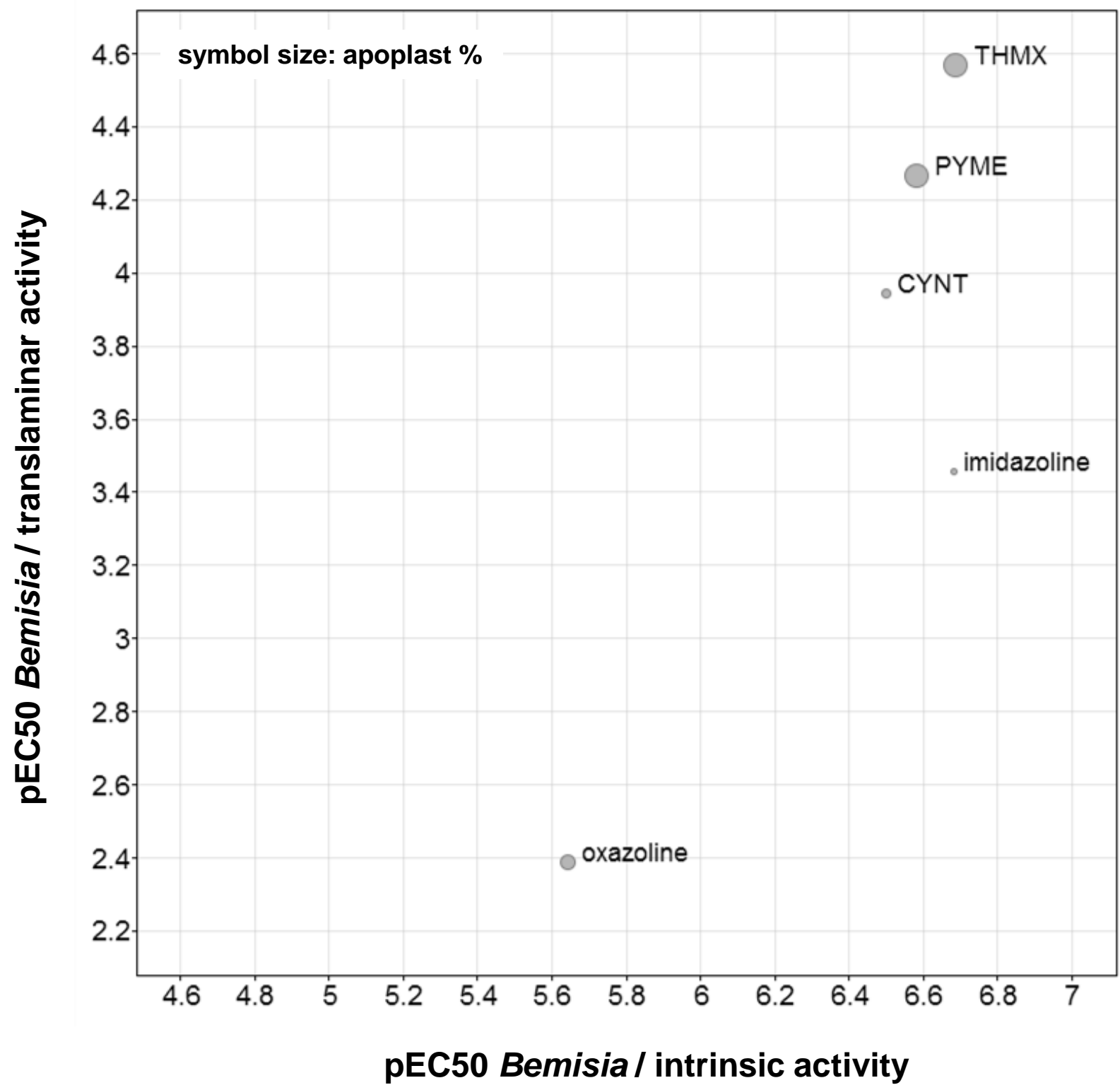

Figure 3. Plot of the log effective concentration of $50 \%$ mortality (pEC50) against Bemisia tabaci in the translaminar assay versus the intrinsic activity against Bemisia (pEC50). The symbol size reflects the calculated mass fraction in the apoplast (Table $4)$. 
Table 1. Physico-chemical characteristics of test compounds studied. Commercial insecticides of A DuPont, B Bayer CropSciences, C Syngenta and research compounds of Syngenta: $1=$ WO 2008/017816, 2 = WO 2008/098657. MW is molar mass in $\mathrm{g} / \mathrm{mol}$; Vx is molar volume (calculated by ACD) Data source: manufacturer and Syngenta.

\begin{tabular}{|c|c|c|c|c|c|c|c|}
\hline & Cyantraniliprole $^{A}$ & Spirotetramat $^{B}$ & $\begin{array}{l}\text { Spirotetramat } \\
\text { enol }^{B}\end{array}$ & Oxazoline $^{\top}$ & Imidazoline $^{2}$ & Pymetrozine $^{C}$ & Thiamethoxam $^{C}$ \\
\hline $\begin{array}{l}\text { Abbrevia- } \\
\text { tion }\end{array}$ & CYNT & SPAT & SPAT enol & OX & IM & PYME & THMX \\
\hline $\begin{array}{l}\text { Log Kow } \\
\text { neutral }\end{array}$ & 1.94 & 2.51 & 2.20 & 2.34 & 4.29 & -0.23 & -0.13 \\
\hline $\begin{array}{l}\text { Log Kow } \\
\text { ion }\end{array}$ & -1.56 & -0.99 & -1.30 & -1.16 & 0.79 & -3.73 & -3.63 \\
\hline pKa & 9.1 & 10.7 & 5.2 & 8.7 & 9.4 & 4.1 & / \\
\hline Valency & -1 & -1 & -1 & +1 & +1 & +1 & +1 \\
\hline MW & 474 & 373 & 301 & 220 & 300 & 217 & 292 \\
\hline Vx & 293.9 & 310.8 & 257.6 & 159.1 & 245.3 & 162.6 & 170.3 \\
\hline
\end{tabular}


Table 2. Compartment properties. E of cytosol is the electrical potential at the biomembrane (plasmalemma) between cytosol and outside, E of vacuoles, phloem and xylem are to cytosol (Source: Trapp 2007).

\begin{tabular}{|l|l|r|r|r|r|r|}
\hline Parameter & Unit & Apoplast & Cytosol & Vacuole & Phloem & Xylem \\
\hline \% volume of cell & $\%$ & - & 10.6 & 84.8 & - & - \\
\hline \% volume of leaf & $\%$ & $30 *$ & 5.3 & 42.4 & 2.3 & 2.3 \\
\hline $\mathrm{pH}$ inside & & & 7.2 & 5.5 & 8 & 5.5 \\
\hline $\mathrm{pH}$ outside & & & 5.6 & 7.2 & 7.2 & 7.2 \\
\hline lipid & $\mathrm{L} / \mathrm{L}$ & & 0.05 & 0.05 & 0 & 0 \\
\hline water & $\mathrm{L} / \mathrm{L}$ & & 0.95 & 0.95 & 1 & 1 \\
\hline lon strength & $\mathrm{mol}$ & & 0.3 & 0.3 & 0.3 & 0.01 \\
\hline E electrical field & $\mathrm{V}$ & & $-1.00 \mathrm{E}-01$ & $2.00 \mathrm{E}-02$ & $3.00 \mathrm{E}-02$ & $1.00 \mathrm{E}-01$ \\
\hline
\end{tabular}

* plus $10 \%$ gas phase, ignored here 
Table 3. Molar effective concentrations pEC50 of test compounds against red-spotted spider mites, Tetranychus urticae Koch; whiteflies Bemisia tabaci Gennadius; cowpea aphids Aphis craccivora Koch and peach-potato aphids Myzus persicae Sulz. High values indicate low EC50 and strong potency (unit $-\log (\mathrm{mol} / \mathrm{L}))$. n.t. means not tested.

(In brackets: 95\% Cl. Lacking data: pEC50 calculations were done with means since shape of dose-response curve did not allow calculations for each replicate).

\begin{tabular}{|c|c|c|c|c|c|c|c|}
\hline pEC50 & Cyantraniliprole & Spirotetramat & $\begin{array}{l}\text { Spirotetramat } \\
\text { enol }\end{array}$ & Oxazoline & Imidazoline & Pymetrozine & Thiamethoxam \\
\hline Tetranychus / curative & n.t. & $\begin{array}{c}5.1 \\
(0.28)\end{array}$ & $\begin{array}{c}5.2 \\
(0.05)\end{array}$ & $\begin{array}{c}5.0 \\
(0.24)\end{array}$ & $\begin{array}{c}5.6 \\
(0.24)\end{array}$ & n.t. & n.t. \\
\hline Tetranychus / translaminar & n.t. & $\begin{array}{c}4.2 \\
(0.31)\end{array}$ & $\begin{array}{c}4.1 \\
(0.42)\end{array}$ & $\begin{array}{c}4.6 \\
(0.10)\end{array}$ & $\begin{array}{c}4.4 \\
(0.27)\end{array}$ & n.t. & n.t. \\
\hline Bemisia / intrinsic & $\begin{array}{c}6.5 \\
(0.04)\end{array}$ & n.t. & n.t. & $\begin{array}{c}5.6 \\
(0.13)\end{array}$ & $\begin{array}{c}6.7 \\
(0.19)\end{array}$ & $\begin{array}{c}6.6 \\
(0.35)\end{array}$ & $\begin{array}{c}6.7 \\
(0.22)\end{array}$ \\
\hline Bemisia / curative & $\begin{array}{c}4.4 \\
(0.14)\end{array}$ & $\begin{array}{c}5.1 \\
(0.16)\end{array}$ & $\begin{array}{c}5.2 \\
(0.23)\end{array}$ & 5.1 & $\begin{array}{c}4.9 \\
(0.07)\end{array}$ & 5.4 & $\begin{array}{c}4.4 \\
(0.11)\end{array}$ \\
\hline Bemisia / translaminar & $\begin{array}{c}3.9 \\
(0.24) \\
\end{array}$ & $\begin{array}{c}4.2 \\
(0.49) \\
\end{array}$ & $\begin{array}{c}3.5 \\
(0.34) \\
\end{array}$ & $\begin{array}{c}2.4 \\
(0.41) \\
\end{array}$ & $\begin{array}{c}3.5 \\
(0.13) \\
\end{array}$ & $\begin{array}{c}4.3 \\
(0.58) \\
\end{array}$ & $\begin{array}{c}4.6 \\
(0.37) \\
\end{array}$ \\
\hline Aphis / intrinsic & $\begin{array}{c}6.2 \\
(0.16)\end{array}$ & $\begin{array}{c}5.8 \\
(0.02)\end{array}$ & $\begin{array}{c}6.5 \\
(0.30)\end{array}$ & $\begin{array}{c}7.2 \\
(0.20)\end{array}$ & $\begin{array}{c}7.3 \\
(0.22)\end{array}$ & $\begin{array}{c}7.3 \\
(0.11)\end{array}$ & $\begin{array}{c}6.9 \\
(0.14)\end{array}$ \\
\hline Aphis / curative & $\begin{array}{c}5.4 \\
(0.20)\end{array}$ & 6.0 & 5.8 & 7.1 & $\begin{array}{c}5.6 \\
(0.31)\end{array}$ & 5.3 & $\begin{array}{c}5.4 \\
(0.13)\end{array}$ \\
\hline Aphis / translaminar & $\begin{array}{c}4.5 \\
(0.35) \\
\end{array}$ & $\begin{array}{c}4.8 \\
(0.51)\end{array}$ & $\begin{array}{c}3.7 \\
(0.55)\end{array}$ & $\begin{array}{c}4.8 \\
(0.33) \\
\end{array}$ & $\begin{array}{c}4.2 \\
(0.33) \\
\end{array}$ & $\begin{array}{c}4.5 \\
(0.25) \\
\end{array}$ & $\begin{array}{c}4.9 \\
(0.17) \\
\end{array}$ \\
\hline Myzus / intrinsic & $\begin{array}{c}6.3 \\
(0.44)\end{array}$ & $\begin{array}{c}6.1 \\
(0.38)\end{array}$ & $\begin{array}{c}6.1 \\
(0.18)\end{array}$ & $\begin{array}{c}7.5 \\
(0.24)\end{array}$ & $\begin{array}{c}6.4 \\
(0.26)\end{array}$ & $\begin{array}{c}6.3 \\
(0.18)\end{array}$ & $\begin{array}{c}6.8 \\
(0.36)\end{array}$ \\
\hline
\end{tabular}


Table 4. Calculated mass distribution (\%) in a leaf cell, concentration ratio phloem to outside apoplast and xylem to outside apoplast, resistances $(\mathrm{s} / \mathrm{m})$ in apoplast and symplast, overall half-time for transfer $\mathrm{t}_{1 / 2}$ (d) from top to downside, and percentage leaf and cuticle penetration. Calculated solute mobilities $\log \mathrm{k}^{*}\left(\mathrm{~s}^{-1}\right)$ in isolated apple leaf cuticles (Malus CM) according to Buchholz et al. 1998 and resultant penetration in \% within $1 \mathrm{~d}$.

\begin{tabular}{|c|c|c|c|c|c|c|c|}
\hline & CYNT & SPAT & $\begin{array}{l}\text { SPAT } \\
\text { enol }\end{array}$ & OX & IM & PYME & THMX \\
\hline apoplast \% & 11.0 & 3.6 & 8.9 & 20.4 & 1.0 & 43.4 & 43.7 \\
\hline Cytosol \% & 9.9 & 10.7 & 54.2 & 0.4 & 4.4 & 6.0 & 6.3 \\
\hline Cytosol dissolved \% & 1.5 & 0.5 & 50.9 & 0.3 & 0.7 & 5.7 & 6.0 \\
\hline Vacuole \% & 79.1 & 85.7 & 36.9 & 79.2 & 94.6 & 50.7 & 50.0 \\
\hline C Phloem & 0.9 & 0.8 & 202 & 0.02 & 0.8 & 0.8 & 0.8 \\
\hline C Xylem & 1.0 & 1.0 & 0.9 & 1.2 & 1.1 & 1.0 & 1.0 \\
\hline $\begin{array}{l}\text { resistance apoplast } \\
(\mathrm{s} / \mathrm{m})\end{array}$ & 280 & 759 & 275 & 103 & 2477 & 48 & 55 \\
\hline $\begin{array}{l}\text { resistance symplast } \\
(\mathrm{s} / \mathrm{m})\end{array}$ & 510 & 712 & 671 & 26500 & 6914 & 14228 & 10879 \\
\hline$t_{1 / 2}(d)$ & 0.013 & 0.026 & 0.014 & 0.007 & 0.126 & 0.003 & 0.004 \\
\hline $\begin{array}{l}\text { Leaf penetration } \\
t=1 \mathrm{~h}(\%)\end{array}$ & 90 & 68 & 88 & 98 & 20 & 99.9 & 99.9 \\
\hline $\begin{array}{l}\text { Leaf penetration } \\
\mathrm{t}=1 \mathrm{~d}(\%)\end{array}$ & 100 & 100 & 100 & 100 & 99 & 100 & 100 \\
\hline $\log k^{*}\left(s^{-1}\right)$ & -6.89 & -7.05 & -6.55 & -5.61 & -6.43 & -5.65 & -5.72 \\
\hline $\begin{array}{l}\text { Cuticle penetration } \\
\mathrm{t}=1 \mathrm{~d}(\%)\end{array}$ & 1.1 & 0.8 & 2.4 & 21.0 & 3.2 & 19.5 & 16.5 \\
\hline
\end{tabular}


Table 5. Strongly simplified feeding sites of model arthropods

\section{Mites Aphids Whiteflies}

$\begin{array}{lll}\text { Phloem } & \sqrt{ } & \sqrt{ } \\ \text { Xylem } & \sqrt{ } & \sqrt{ } \\ & & \end{array}$

Cytosol $\sqrt{ } \quad \sqrt{ }$

Vacuole $\sqrt{ } \sqrt{ }$ 